\title{
Servant leadership, trust and implications for the "Base-of-the-Pyramid" segment in South Africa
}

\author{
A. Chatbury \\ Sasol Ltd \\ D. Beaty* \\ Gordon Institute of Business Science, University of Pretoria, \\ Republic of South Africa \\ docbeaty@2btassociates.com \\ H.S. Kriek \\ Wits Business School, University of the Witwatersrand, \\ Johannesburg 0002, Republic of South Africa \\ docbeaty@2btassociates.com
}

Received June 2010

\begin{abstract}
This paper examines the relationship between servant leadership and interpersonal trust in South Africa. The results of this empirical investigation, conducted among low level employees and their managers, revealed a statistically significant relationship between servant leadership and interpersonal trust using Spearman's r-value of 0.664 ( $p<0.05)$. These findings will be discussed in terms of their implications for establishing what kind of leadership model might work at the Base of the Pyramid (BOP) and how this approach might build trust among stakeholders in the informal economy in South Africa.
\end{abstract}

*To whom all correspondence should be addressed.

\section{Introduction}

The purpose of this paper is to examine the relationship between servant leadership and interpersonal trust in South Africa. The findings will be discussed in terms of their implications for leaders' building trust with communities and stakeholders in the informal economy in South Africa.

A growing number of authors argue that a large and viable market exists in the informal economy of the world that has remained largely invisible to the corporate sector (Prahalad \& Hart, 2002; Martinez \& Carbonelli, 2007; Seelos \& Mair, 2007). This segment of the market is often referred to as the "Tier 4 arena" (Prahalad \& Hart, 2002) and the "Bottom of the Pyramid" (Prahalad, 2004). What's more, these authors argue that it is imperative that managers recognize the nature of the business leadership required in the Tier 4 arena. For example, Prahalad and Hart (2002) assert that leaders need a deep understanding of the complexities and subtleties of sustainable development in the context of Tier 4. They indicate that managers must have the interpersonal and intercultural skills to work with a wide range of organisations and people. Pitta, Guesalaga and Marshall (2008: 400) support this conclusion and add that "an accurate characterization of the low-income sector - both as consumers and as producers - is required to understand their needs, perceptions, and behaviour which in turn will help companies to design a better business approach". Gardetti (2005) adds that it should be established what kind of business model will work and how can it build trust in the informal economy?

The relationship between leadership and trust in creating positive relations between stakeholders groups has been validated by a number of authors (Yukl, 2006; Hughes, Ginnett \& Curphy, 2006; Joseph, \& Winston, 2005). Indeed, a large body of literature exists showing many alternative models of leadership including leadership as a trait (Northouse, 2003), a skill (Katz, 1955), a style (Blake \& Mouton, 1985), situational leadership (Hersey \& Blanchard, 1982), motivational (House, Javidan \& Dorfman, 2001) and transformational (Bass \& Avolio, 1994). A model of leadership that potentially could be particularly appropriate for building trust relationships at the Bottom of the Pyramid (BOP) is the servant leadership model (Greenleaf, 2004). Greenleaf (2004: 387) asks in order to test leadership effectiveness one has to answer for example "Do those served grow as persons? Do they, while being served, become healthier, wiser, freer, more autonomous, and are they more likely themselves to become servants? And what is the effect upon the least privileged in society; will they benefit or at least not be further deprived?" Although the concept of servant leadership has been in existence since the early seventies, it is only relatively recently that researchers 
have examined this particular model of leadership empirically (Humphreys, 2005). For example, Joseph and Winston (2005) concluded in their research that servant leadership is both a product, and an antecedent, of leader and organizational trust. They assert that servant leaders earn trust because they empathize with and fully accept followers, are dependable due to their foresight and intuition, and lead by example. Further, because servant leaders are concerned for their follower's interests and place them over their own, they are able to earn their followers' trust.

However, while the majority of leadership theories have originated in the West (Kriek, Beaty \& Nkomo, 2009), there are few models of leadership that have been empirically tested outside of the United States or in South Africa (Beaty, Nkomo \& Kriek, 2006). Yet, Covey (2006) suggests that the servant leadership approach might be particularly appropriate for South Africa because this model is characterized by moral authority, humility, service and sacrifice in order to foster trust and respect, the critical foundations of teamwork. He offers Nelson Mandela as an example of a servant leader. Kriek et al. (2009) suggest that the African concept of Ubuntu, which embraces hospitality, caring about others, being willing to go the extra mile for another and that a person is a person through other persons, is also consistent with the servant leadership approach.

This study attempts to examine the relationship between servant leadership and interpersonal trust in South Africa and points out implications from the findings for creating trust relations between stakeholders at the BOP in this country.

\section{Research design}

\section{Research approach}

A survey design (Shaughnessy \& Zechmeister, 1997) was used to examine the relationship between servant leadership and interpersonal trust.

\section{Participants}

The target population was 411 employees employed within two procurement and supply management departments in two divisions of a publicly listed South African Petrochemical firm. A stratified random sample of 190 employees was selected from this population and a response rate of $72 \%$ was obtained. This sample comprised a majority in the age group of 40-49 (29.84\%), a level of tenure of 20 or more years of work experience $(27.4 \%)$ and the majority of the sample was employed at a Junior Administrative level $(43.09 \%)$.

\section{Measuring instruments}

Two measuring instruments, namely the Servant Leadership Behaviour Scale (Sendjaya, Sarros \& Santora, 2008) and the Organisational Trust Indicator (Nyhan \& Marlowe, 1997) were used in the present study and will be explained briefly.

\section{Servant leadership behaviour scale}

The instrument used to assess the extent of servant leadership behaviours in this study was the Servant Leadership Behaviour Scale (SLBS) developed by (Sendjaya et al., 2008). These authors contend that the SLBS is based on behaviours identified for servant leaders by numerous researchers in the literature. Further, they indicate that the instrument differs from other measures of servant leadership such as Laub's (2005) Organisational Leadership Instrument (OLA) and Barbuto, Daniel and Wheeler's (2006) Servant Leadership Questionnaire (SLQ) because it also measures the spiritual and moral-ethical dimensions of servant leadership (Sendjaya, et al., 2008).

The SLBS measures 6 servant leadership dimensions and comprises 35 items. The 6 dimensions include: Voluntary subordination (VS), Authentic Self (AS), Covenantal Relationships (CR), Responsible Morality (RM), Transcendental Spirituality (TS) and Transforming Influence (TI). Items that measure sub-dimensions of servant leadership are: VS - being a servant; AS - Acts of Service, Humility, Integrity, Accountability, Security, Vulnerability; CR - Acceptance, Availability, Equality, Collaboration; RM - Moral Reasoning, moral action; TS Religiousness, Interconnectedness, Sense of Mission, Wholeness; TI - Vision, Modeling, Mentoring, Trust, and Empowerment.

Sendjaya et al. (2008) indicate that reliability of the SLBS was verified by testing for internal consistency for the items comprising each of the 6 factors and by comparing assessed correlation coefficients for each factor with the recommended value of 0.70 for Cronbach's alpha (Diamantopoulos \& Schlegelmilch, 2005). Sendjava et al. (2008) also indicated that the internal consistency of the instrument has been validated.

\section{Organisational trust inventory}

The measuring instrument used to assess interpersonal trust was the Organizational Trust Inventory (Nyhan \& Marlowe, 1997). This instrument is a 12 -item measure designed to measure an individual's level of trust in his/her supervisor ( 8 items) and organization (4 items). These authors calculated inter-item reliability using Cronbach's alpha (Diamantopoulos \& Schlegelmilch, 2005) and the results varied for different samples between 0.92 and 0.96. Testretest reliability was relatively high at 0.84 , and an exploratory factor analysis revealed results for both interpersonal and organizational trust loaded consistently on these two factors (Nyhan \& Marlowe, 1997).

Convergent validity was confirmed by correlating scores on the Organisational Trust Inventory (OTI) with other measures such as job stress, job satisfaction, organizational culture and affective commitment (Nyhan \& Marlowe, 1997). These authors found that, in all cases, correlations were consistent with theoretically expected and hypothesized relationships between levels of trust and other factors being assessed and confirmed the convergent validity of the instrument. 
For purposes of this investigation, however, only eight items in the OTI that measured the level of trust between the participant's direct supervisor and each participant reporting to the supervisor were selected for the research. This is because the focus of this study concerns solely the trust relationship and perceptions of servant leadership between the supervisor and employee.

\section{Procedure}

The authors compiled a list of 190 employees using name lists provided by Human Resources Consultants in each of the two divisions of the firm. Participants were mailed hard copies of the two instruments which included an introduction to the research, a request to complete the questionnaires and instructions on how to complete the instrument. Confidentiality and anonymity were guaranteed and respondents were not requested to reveal their names or identities. Questionnaires were scored according to the instructions of their authors' and the data transferred to a Microsoft Excel spreadsheet and statistical database (StatSoft, 2008).

Respondents were requested to rate the extent to which the individual's direct supervisor displays a specific servant leadership behaviour using a 5-point Likert scale from $0=$ Strongly Disagree to $5=$ Strongly Agree. Respondents were also requested to complete the Organisational Trust
Inventory by rating the 4 items that indicated trust levels between the direct supervisor and participant and rating each item using a 7-point Likert scale from $0=$ Nearly Zero to 7 $=$ Near $100 \%$.

\section{Statistical analysis}

To test for the relationship between servant leadership and interpersonal trust, a scatterplot of mean servant leadership and interpersonal trust scores were plotted and a Pearson-r was calculated. A statistical analysis was conducted using the Kolmogorov-Smirnov test for normality and the Lilliefors p-value. A Spearman's rank-order correlation coefficient was also conducted on the data to test for significance of the relationship. A cut-off point of $\mathrm{p}<0.05$ was set for the interpretation of the statistical significance of the results.

\section{Results}

The Statistica scatterplot of servant leadership mean scores and interpersonal trust mean scores and the calculated value of for Pearson's-r are reported in Figure 1. These results indicate that there is a significant and positive relationship between servant leadership and interpersonal trust in terms of the opinion of the sample employed in this study.

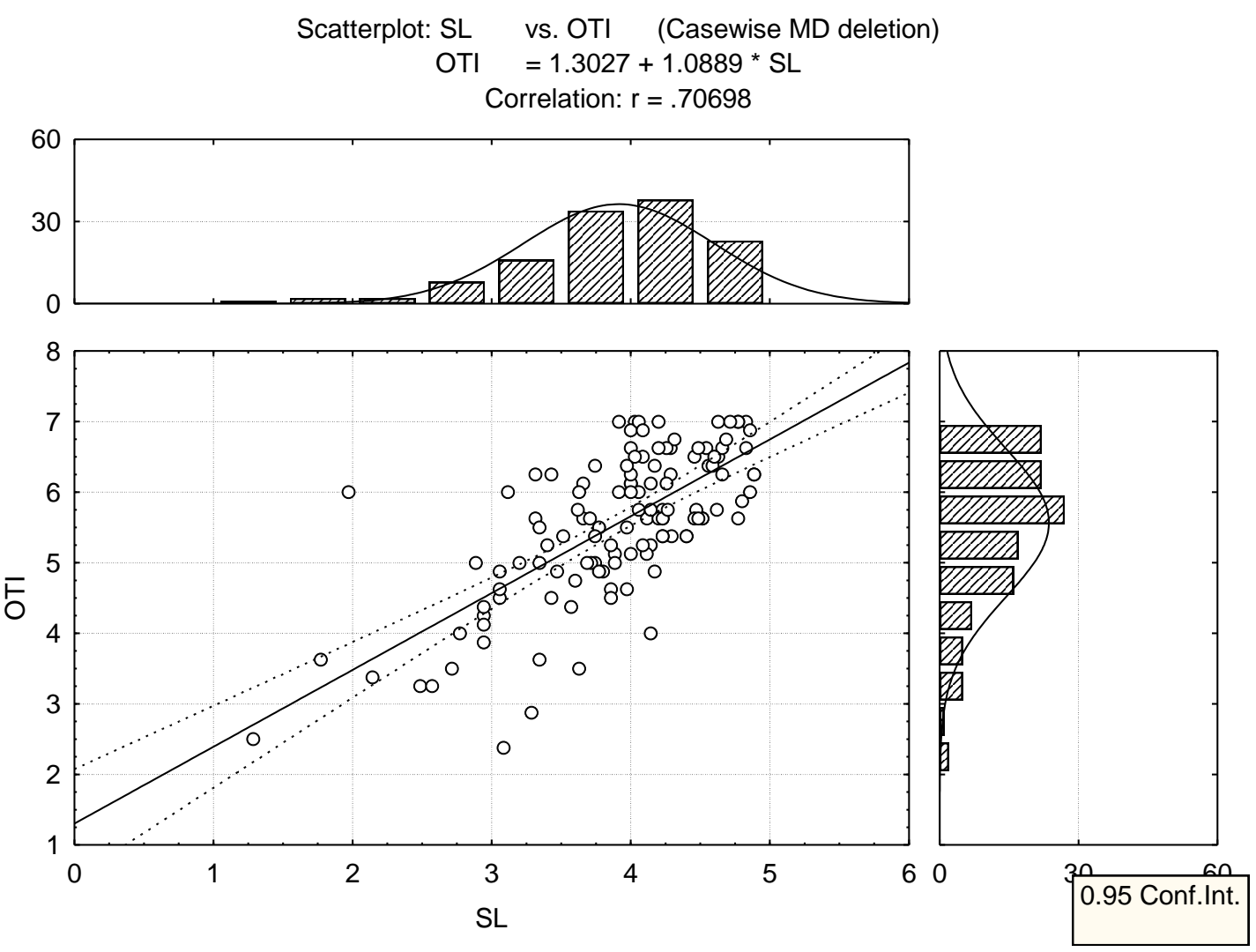

Figure 1: Statistica scatterplot and calculated Pearson's-r for correlation between servant leadership mean scores and interpersonal trust mean scores 
The results of a further analysis of the data using the Spearman's rank order test for significance is reported in Table 2. These results indicate a Spearman's r-value of 0.664 and is statistically significant at the $\mathrm{p}<0.05$ level.

Table 1: Spearman's rank-order correlation and test for significance for mean servant leadership and interpersonal trust scores

\begin{tabular}{l|l|l}
\hline Variable & $\begin{array}{l}\text { Spearman rank Order Correlations } \\
\text { MD pair-wise deleted } \\
\text { Marked correlations are significant at } \mathbf{P}<.05\end{array}$ \\
\cline { 2 - 3 } & SL & OTI \\
\hline SL & 1,0 & 0,664164 \\
\hline OTI & 0,664164 & 1,0 \\
\hline
\end{tabular}

These results indicate that there is both a positive (Figure 1) and statistically significant (Table 1) relationship between servant leadership and interpersonal trust in terms of the sample findings in this survey research.

\section{Conclusions}

The results of this investigation reveal a positive and significant relationship between servant leadership and trust in a sample of low-level workers and their managers in a South African firm. These findings suggest that this model of leadership has the potential to enhance interpersonal trust between workers and their managers in South Africa.

The authors emphasise, however, that the findings of this research should not be generalized to specific BOP samples and populations in the informal economy and Tier 4 population segments. These segments are complex and require different business models than traditionally practiced (D’Andrea, Stengel, \& Goebel-Krstelj, 2004). However, while caution is warranted in generalizing these results to the BOP segment, the study holds implications for researchers and practitioners studying new and different ways to engender stakeholder trust at the BOP. For example, servant leaders emphasize the growth and development of their followers above other objectives (Greenleaf, 2004). They are first and foremost, servants, and conscious choice brings them to aspire to lead (Greenleaf, 2004). This makes them sharply different to conventional leaders, who either prioritize business objectives above the growth and development of their people, or lead in order to assuage a power drive or satisfy desires for material gain. Servant leaders understand that a company exists in order to serve the needs of its stakeholders and that profit is but a means to a higher purpose (Covey, 2006; Spears, 2004; Bennis, 2004). They also understand that the business will only be effective in meeting its objectives effectively in the long term by prioritizing the growth and development of its people (Stone, Russell \& Patterson, 2004).

This study has added to available evidence (Joseph \& Winston, 2005) that leaders enjoy higher levels of interpersonal trust with their followers when they display servant leader behaviours, by finding a moderate to strong correlation (Spearman's rank-order correlation coefficient of 0.664 ) between servant leadership and interpersonal trust. The study's finding indicates that leaders are likely to increase the levels of interpersonal trust that exist between themselves and their followers by increasing the extent to which they display servant leader behaviours.

Thus, these findings hold important implications for BOP researchers and practitioners. For example, Pitta, Guesalaga and Marshall (2008) indicate that if the goal of firms is poverty eradication at a profit, all the players must cooperate and achieving teamwork is essential. A number of authors assert that successful engagement in the BOP context requires a collaborative approach for business with social partners such as government, NGO's and communities (Beshouri, 2006; Harjula, 2005).

Further research is needed that specifically targets the specific segment of the BOP and examines the relationship between servant leadership and trust with this specific population in South Africa. However, this research suggests that the model of servant leadership has potential application for engendering trust relations essential for cooperation, teamwork and collaboration between stakeholders both within organisations as well as with stakeholders outside firms at the BOP.

Thus, this study indicates a relationship between servant leadership and interpersonal trust in South Africa and points out that servant leadership could improve levels of trust between stakeholders at the BOP in this country.

\section{References}

Barbuto, J.E., Daniel, J.R. \& Wheeler, W. 2006. 'Scale development and construct clarification of servant leadership', Group and Organization Management, 31(3): 300-326.

Bass, B.M. \& Avolio, G.J. 1994. Improving organisational effectiveness through transformational leadership. Thousand Oaks, Calif.: Sage.

Bennis, W. 2004. 'Foreword. Why servant leadership matters'. In: Spears, L.C. \& Lawrence, M. (eds.). Practicing servant leadership: Succeeding through trust, bravery, and forgiveness. San Francisco: Jossey-Bass. xi-xvi.

Beaty, D., Nkomo, S. \& Kriek, H.S. 2006. 'Management theory building in South Africa: An archival analysis', Management Dynamics, 15(2): 48-63

Beshouri, C. 2006. 'A grassroots approach to emerging market consumers', Mckinsey Quarterly, 10(3):61-67.

Blake, R. \& Mouton, J.S. 1985. The Managerial Grid III. Houston, Texas: Gulf.

Blanchard, K. \& Hodges, P. 2003. The servant leader transforming your heart, head, hands and habits. Nashville: J Countryman.

Covey, S.R. 2006. 'Servant leadership: Use your voice to serve others', Leadership Excellence, 23(12): 5-6. 
D'Andrea, G. Stengel, E.A. \& Goebel-Krstelj, A. 2004. 'Six truths about emerging-market consumers', Strategy and Business, 34: 2-12.

Diamantopoulos, A. \& Schlegelmilch, B.B. 2005. Taking the fear out of data analysis. London: Thomson Learning.

Gardetti, M.A. 2005. 'A base of the pyramid approach in Argentina', Greener Management International, 51: 65-77.

Greenleaf, R.K. 2004. 'Who Is the servant leader?' In: Spears, R.C. (ed.). Practicing servant leadership: Succeeding through trust, bravery and forgiveness. San Francisco: Jossey-Bass, pp. 1-8.

Harjula, L. 2005. 'Tensions between venture capitalists and business-social entrepreneurs' goals: Will bottom-of-thepyramid strategies offer a solution?' Greener Management International, 51: 79-87.

Hersey, P. \& Blanchard, K.H. 1982. 'Management of organisational behaviour; Utilizing human resources,, $4^{\text {th }}$ Edition. NJ: Prentice Hall

House, R., Javidan, M. \& Dorfman, P. 2001. 'Project GLOBE: An introduction', Applied Psychology: An International Review, 50(4): 489-505.

Hughes, R.L., Ginnett, R.C. \& Curphy, G.J. 2006. Leadership: Enhancing the lessons of experience. $5^{\text {th }}$ Edition. Singapore: McGraw-Hill.

Humphreys, J.H. 2005. 'Contextual implications for transformational and servant leadership', Management Decision. 43(10): 1410-1431.

Joseph, E.E. \& Winston, B.E. 2005. 'A correlation of servant leadership, leader trust, and organizational trust', Leadership \& Organization Development Journal, 26(1):622.

Katz, R. 1955. 'Skills of an effective administrator', Harvard Business Review, Jan-Feb:33-42.

Kriek, H.S., Beaty, D.T. \& Nkomo, S. 2009. 'Theory building trends in international management research: An archival review of preferred methods, South African Journal of Economic and Management Sciences, 12(1):126-135.

Laub, J. 2005. 'From paternalism to the servant organization: Expanding the Organizational Leadership Assessment (OLA) Model', The International Journal of Servant-Leadership, 1(1):155-186. (Spokane: Gonzaga University in collaboration with The Greenleaf Centre for Servant-Leadership).

Martinez, J.L. \& Carbonelli, M. 2007. 'Value at the bottom of the pyramid,' Business Strategy Review, Autumn: 50-55.

Northhouse, P. 2003. Leadership: Theory and practice. Thousand Oaks: Sage.
Nyhan, R.C. \& Marlowe, H.A. Jr. 1997. 'Development and psychometric properties of the organizational trust inventory', Evaluation Review, 21(5): 614-635.

Pitta, D. Guesalaga, R. \& Marshall, P. 2008. 'The quest for the fortune at the bottom of the pyramid: Potential and challenges', Journal of Consumer Marketing. 25(7): 393401.

Prahalad, C.K. 2004. The fortune at the bottom of the pyramid: Eradicating poverty through profits. Upper Saddle River, N.J: Wharton School Publishing.

Prahalad, D. K. \& Hart, S.L. 2002. 'Serving the world's poor profitably', Harvard Business Review, 80(9): 48-57.

Seelos, C. \& Mair, J. 2007. 'Profitable business models and market creation in the context of deep poverty: A strategic view', Academy of Management Perspectives. Nov: 49-63.

Sendjaya, S., Sarros, J.C. \& Santora, J.C. 2008. 'Defining and measuring servant leadership behaviour in organisations,' Journal of Management Studies, 45(2):402424.

Shaughnessy, J.J. \& Zechmeister, E.B. 1997. Research methods in psychology. New York: McGraw-Hill.

Spears, R.C. 2004. 'Practicing servant-leadership', Leader to Leader, 34 (Fall): 7-11.

Stone, A.G., Russell, R.F. \& Patterson, K. 2004. 'Transformational versus servant leadership: A difference in leader focus', The Leadership \& Organisational Development Journal, 25(4): 349-361.

StatSoft, Inc. 2008. 'Statistica 8 trial version download'. [online] URL:

https://www.statsoft.com/secure/statistica8trial html. Accessed 5 September 2008.

Yukl, G. 2006. Leadership in organizations. $6^{\text {th }}$ Edition. New Jersey: Prentice-Hall. 
